\title{
Teacher Support for Eliciting Students Mathematical Thinking: Problem Posing, Asking Questions, and Song
}

\author{
Ary Woro Kurniasih, Isti Hidayah and Mohammad Asikin \\ Department of Mathematics, Faculty of Mathematics and Natural Sciences, \\ Semarang State University, Semarang, Indonesia \\ https://orcid.org/0000-0003-1674-4226 \\ https://orcid.org/0000-0001-8462-3376 \\ https://orcid.org/0000-0003-1121-3629
}

\begin{abstract}
Mathematical thinking and reasoning are at the core of mathematics learning, strategies to facilitate their development are global issues for various countries. This qualitative study aims to describe the fifth-grade elementary school teacher's stimulus form, to expand students' thinking ability in mathematics learning and obtain a stimulus formulation of the fifth-grade elementary school teacher in developing students' mathematical thinking ability. Data were obtained by using open-ended questionnaire methods and passive participation observation. The study results showed that the stimulus form of the fifthgrade elementary school teacher in expanding students' thinking skill in learning the mathematics comprises problem posing, asking guiding questions, facilitating technology (learning videos/PowerPoint/Plickers), and song. The recommendation of fifthgrade elementary school teacher stimulus for developing students' mathematical thinking ability was asking the probing question, playing, and games. Furthermore, the results of the second year's research were widely disseminated to teachers. Primary school teachers who are part of the teacher working group also need to improve their professionalism, especially concerning developing stimulus thinking and applying it in learning. Therefore, the follow-up as the management of learning in the form of INNOMATTS training.
\end{abstract}

Keywords: guiding question; mathematical thinking; problem posing; song; students thinking

\section{Introduction}

The enforcement of education in Indonesia has followed its 2013 curriculum since the academic year 2013/2014. Because mathematical thinking and reasoning are at the core of mathematics learning, strategies to facilitate their development are global issues for various countries and organizations, including the Australian 
Curriculum and Assessment Reporting Authority (Harrington, 2008) and the National Council of Teachers of Mathematics (NCTM) (2017a). In Indonesia, the country has followed its 2013 curriculum since the academic year 2013/2014. This curriculum is based on Regulation of Ministry of Education and Culture Republic of Indonesia No. 21 of 2016 (Ministry of Education and Culture Republic of Indonesia, 2016), which concerns elementary and secondary education content standards. It identifies three graduate competencies: attitude, knowledge, and skill. These three competencies are further broken down into four dimensions, or core competencies: spiritual, social, knowledge, and skill. Regulation of Ministry of Education and Culture Republic of Indonesia No. 37 of 2018 (Ministry of Education and Culture Republic of Indonesia, 2018) states that for the fifth-grade elementary school student, the core competency of knowledge means the ability of the students to comprehend knowledge both of factual and conceptual by inspecting and questioning based on curiosity about himself, God's creatures and their activities, and the objects found at daily life. Students' questioning activity is, therefore, the way in which they will attain knowledge competency. According to Tofade, Elsner, and Haines (2013), a question is a learning tool that can stimulate critical thinking. Questions asked must be analytical, essential, and creative so that the questioning activity conducted by the students has a role in encouraging high thinking competency (Samo, Darhim, \& Kartasasmita, 2017). Such activity is thus seen as critical to developing a student's ability to thinkand thereby learn - in the mathematical context.

The Programme for International Student Assessment (PISA) is a worldwide program by the Organisation for Economic Co-operation and Development (OECD). In terms of Indonesian students' mathematics performance, PISA scores in 2003, 2006, 2009, 2012, 2015, and 2018 were 360, 391, 371, 375, 386, and 379, respectively (OECD, 2019). Overall, the performance trajectory in mathematics performance is hump-shaped, i.e., it is more negative over more recent years (OECD, 2019). The 2015 percentage distribution of 15-year-old students on the PISA mathematics literacy scale is presented in Table 1, and that of 2018 is presented in Table 2.

Table 1: The distribution of 15-year-old Indonesian students recorded in the PISA mathematics literacy scale, based on the proficiency level and education system, in 2015

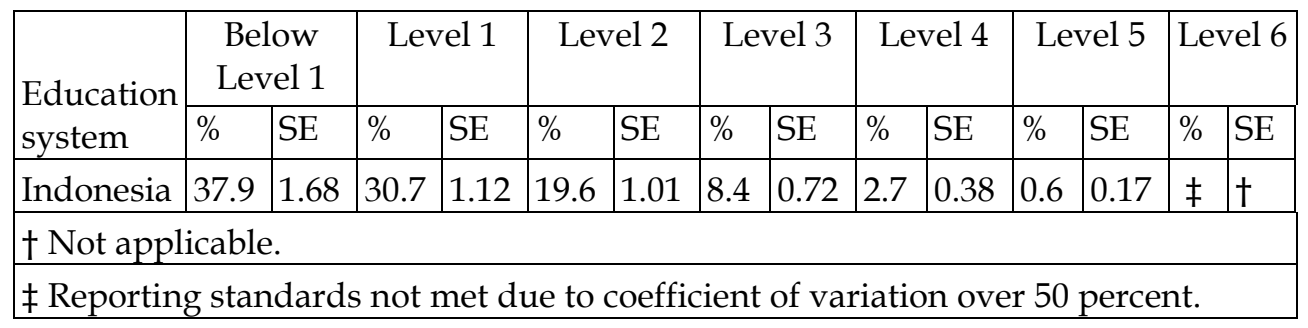

Based on the OECD (2019), there are six proficiencies in mathematics on the PISA scale (from Level 1, the lowest, to Level 6, the highest). Based on Table 1, 68.6\% of students in Indonesia attained Level 1 (i.e., they were proficient below Level 1 and at Level 1). Based on Table 2,71.9\% of students in Indonesia attained Level 1 (i.e., they were proficient below Level 1 and 
at Level 1). Based on Table 1,31.4\% of students in Indonesia attained Level 2 or higher (i.e., they were proficient at Levels 2, 3, 4, 5, or 6). Based on Table 2 , only $28.1 \%$ of Indonesia's students attained Level 2 or higher. According to OECD (2019), students who scored below Level 2 are considered "lowachieving students"; thus, most Indonesian students fall into this category. Based on the OECD (2014), there are six proficiencies in mathematics on the PISA scale (from Level 1, the lowest, to Level 6, the highest). Based on Table 1, 68.6\% of students in Indonesia attained Level 1 (i.e., they were proficient below Level 1 and at Level 1). Based on Table 2, 71.9\% of students in Indonesia attained Level 1 (i.e., they were proficient below Level 1 and at Level 1). Based on Table 1,31.4\% of students in Indonesia attained Level 2 or higher (i.e., they were proficient at Levels $2,3,4,5$, or 6 ). Based on Table 2 , only $28.1 \%$ of Indonesia's students attained Level 2 or higher. According to OECD (2019), students who scored below Level 2 are considered "low-achieving students"; thus, most Indonesian students fall into this category.

Table 2: Indonesian student performance in mathematics (OECD, 2019)

\begin{tabular}{|c|c|c|c|c|c|c|c|c|c|c|c|c|c|c|}
\hline \multirow[b]{3}{*}{ Education system } & \multicolumn{14}{|c|}{ All students } \\
\hline & \multicolumn{2}{|c|}{$\begin{array}{c}\text { Below } \\
\text { Level } 1\end{array}$} & \multicolumn{2}{|c|}{ Level 1} & \multicolumn{2}{|c|}{ Level 2} & \multicolumn{2}{|c|}{ Level 3} & \multicolumn{2}{|c|}{ Level 4} & \multicolumn{2}{|c|}{ Level 5} & \multicolumn{2}{|c|}{ Level 6} \\
\hline & $\%$ & $\mathrm{SE}$ & $\%$ & SE & $\%$ & SE & $\%$ & SE & $\%$ & SE & $\%$ & SE & $\%$ & SE \\
\hline Indonesia & 40.6 & (1.6) & 31.3 & $(1.2)$ & 18.6 & $(1.0)$ & 6.8 & $(0.7)$ & 2.3 & $(0.5)$ & 0.4 & $(0.2)$ & 0.0 & $(0.0)$ \\
\hline
\end{tabular}

The description of proficiency mathematics performance at Level 5 are: (a) students can develop and work with models for building complex berth, identifying constraints and specifying laying claims; (b) students can select, compare, and evaluate appropriate problem-solving strategies for transaction with complex job related to these models; (c) students at this grade can work strategically using broad, well-developed thinking and reasoning science, appropriate linked internal representation, symbolic and formal characterization, and brainstorm about these situations; (d) students have begun to develop the ability to reflect on their work and to communicate determination and rendering in written form; and (e) students master a high level of conceptual understanding and mathematical reasoning (OECD, 2019). Based on Tables 1 and 2, Indonesian students' performance at Level 5 was only $0.6 \%$ and $0.4 \%$ for 2015 and 2018, respectively; this means that they did not yet have maths skills at Level 5 .

The description of proficiency mathematics performance at Level 6 are: (a) students can conceptualize, generalize, and use information based on their investigations and moulding of coordination compound job situations and can use their cognition in relatively non-standard contexts; (b) students can linkup different information sources and representations together and move flexibly among them; and (c) students at this level are capable of advanced mathematical thinking and reasoning. Based on Tables 1 and 2, Indonesian students' performance at Level 6 was $0 \%$ for both 2015 and 2018; this means that their math skills at this level need to be explored and developed. 
To accomplish this goal, mathematical thinking ability must be nurtured at the earliest stages, from basic to secondary education. Mathematical thinking increases the capacities of making estimations and rounding error, measure and constructing, collecting and handling information, representing and interpreting data, recognizing and representing relationships mathematically, using algorithm and relationship, solving trouble, and making decisions among students. When mathematical thinking is at a high grade, students manifest a positive position toward mathematics, encouraging them to approach-and solve-all mathematics problems.

Many researchers in maths education assert the importance of such thinking in assessing the quality of mathematics learning (Cai \& Jiang 2017). Focusing on students' mathematical thinking remains a powerful mechanism for bringing pedagogy, maths, and student understanding together. High-quality mathematics instruction includes three aspects: the teacher's role, classroom discourse, and mathematical tasks (Munter, 2014). Concerning the first aspect, there are three teachers' roles: (a) teacher should engage with educatee in mathematical argument; (b) they should play a proactive role in supporting and scaffolding students' talk by utilizing students' explanation and questions as lesson content, choosing appropriate moment to share essential information such as conventions and alternative methods or articulating important ideas in students' methods; and (c) teachers should ensure that "the responsibility for determining the validity of ideas resides with the classroom community" and not solely with the teacher or the textbook (Munter, 2014).

Moreover, one of the professional skills that mathematics teachers should develop is professional attention. The professional noticing pr professional attention demands that instructor attend to students' thought, interpret their thinking, and decide how to respond based on their own assertions. Noticing student thinking is an important part of the teacher's skill set and in particular, professional noticing about mathematical thinking has garnered the attention of many researchers (Lee, 2018). By adopting this approach, teachers facilitate the learning that in turn leads to the development of mathematical thinking. As they are expected to provide erudition programs from kindergarten through grade XII, teachers or instructors can enable students to recognize reasoning and proofs as basic aspects of mathematics; then further make and investigate mathematical conjectures; also develop and evaluate mathematical arguments and proofs; and choose and use various types of reasoning and verification methods (NCTM, 2017b). Due to the PISA data, NCTM statement, and statements of the experts above, this study conducted on fifth-grade elementary school students. These students are accustomed to developing mathematical thinking naturally and gradually in their classroom environments.

Mathematics teachers' skills for eliciting students thinking is crusial because those skills as a foundation for teaching to help the students get deeply understanding about mathematical ideas. Eliciting student thinking is a core teaching practice 
that is useful in many contexts and content areas (Shaughnessy \& Boerst, 2017), using student thinking to inform the teacher instructional decisions and interactions with students in ways that support student learning (Teuscher et al., 2016). Specifically, learning mathematics equips the student with the ability to develop critical, logical, and abstract thinking skills as well as the confidence to analyze and solve problems in school and daily life situations through the use of creative strategies (Nurlu, 2017). As stated by Harel and Soto (2017) that the way of thinking for each person in terms of making mathematical conclusions and deductions, both as an individual and as a community member, always develops naturally and gradually, with cultural and social interventions. Constructivism views mathematical learning as an active mental construction and understanding process, where students construct the intellectual, knowledge, and understanding abilities not given by the teacher (Lui \& Bonner, 2016). Therefore, mathematics teachers must design classes. Mathematics teachers have become 'designers', or act as 'partners' in the design of curriculum materials not as a 'implementers' of curriculum materials (Jones \& Pepin, 2016). Teachers design and interact with curriculum resources to prepare and set up their teaching in class. They also work with colleagues in school or across schools in local, regional, or international professional development collectives to design and adapt curriculum materials for their own teaching and that of their colleagues (Pepin, Gueudet \& Trouche, 2017). So that students can construct their knowledge through inquiry and discovery, thereby enabling them to develop mathematical creativity. In addition, the teacher provides scaffolding to help with the development of meaningful knowledge. According to the constructivist paradigm, teachers create the context of mathematics learning and pose the questions that will guide students to thinking actively and arguing logically. The mathematical learning activities best suited to this paradigm are probing inquiries and/or discussions; investigations, explorations, and/or discoveries; learning from peers and groups; real-world applications; learning games; using manipulations; and visual representations (Lui \& Bonner, 2016).

In learning practice, the teachers' efforts to elicit student thinking will coincide with their interpretations and responses to such thinking. Teachers help the students bring up ideas; they then make interpretations to pose additional questions to elucidate the students' thinking process, giving responses that encourage the students to learn (Shaughnessy \& Boerst, 2018). This ability, teacher noticing, is referred as a professional vision or lens through which teachers come to view teaching. In this regard, the teacher needs to have the ability to respond to students' thinking during the learning experience. Teacher professional noticing or attention toward children's mathematical thinking involves three simultaneous processes: attending to children's strategies of using their ability; interpreting student responses, work, and solution methods; and deciding, at that moment, how to respond based on student understanding.

In the classroom setting, teachers use various methods to help their students develop mathematical thinking skills. As many as $76 \%$ of questions asked by elementary school teachers (two second grade, one third grade) in Southern California are four types of questions (i.e., general question, specific questions, 
probing sequences of specific questions, and leading questions, $67 \%$ of explanations from second and third grade students in Southern California were true and complete, and $82 \%$ of students' explanations were incomplete, ambiguous, and unclear. Thus, even though the teachers provided a stimulus to encourage student thinking, the further direction was needed to make student responses clear, complete, and unambiguous.

Teachers of mathematics in schools must understand the mathematics being taught and be cognizant of students' mathematical thinking processes (Carpenter \& Lehrer, 1999). To this end, their planning and implementation of mathematics material should open discourse concerning students' thinking and involve students' active participation in learning. Mathematics learning is designed to incorporate several activities to find concepts, ideas, procedures, or principles. Thus, the teacher's activities act as a stimulus to facilitate an improvement in students' thinking abilities (Pratiwi, Herman \& Lidinillah, 2017). However, because it is the teacher's responsibility to develop these activities, organizing a mathematics class is not easy (Anthony, Hunter \& Hunter, 2015). The teachers have to provide challenging mathematical activities that involve the students in asking, justifying, and reflecting, thereby providing a stimulus for fifth-grade students to think.

The research question associated with this study takes two forms: viz. first, what a fifth-grade elementary school teacher uses stimulus for developing students' mathematical thinking abilities; and second, what is the stimulus recommendation of a fifth-grade elementary school teacher for developing students' mathematical thinking abilities. These formulations also become the limitation of this study. As the questions indicate the uniqueness of mathematic teachers undertaking a stimulus for their students' mathematical thinking, any discussion related to students' achievement by applying the stimulus is therefore excluded in this study.

This study illustrates how teacher stimulus brings up students' mathematical thinking in elementary school. Furthermore, it serves as a reference point for the second year of research. Various thought stimuli were implemented to develop students' students' mathematical thinking and test their effectiveness.

\section{Methodology}

\subsection{Research Design}

The research was conducted from May 2018 to September 2018. The research involved 9 teachers of grade 5 elementary school from 9 different schools (in phase 1) and 2 of those 9 teachers (in phase 2) in Gunungpati district, Semarang Indonesia. This study used a descriptive qualitative method and occurred in the academic year 2018/2019. Research activities were divided into several phases. The first phase was a discussion group forum with fifth-grade elementary school teachers, which took place on Saturday, May 12, 2018. Nine teachers participated, and there was no selection activity in UPTD (Unit Pelaksana Teknis Daerah) Gunungpati Semarang. The teachers filled out a questionnaire to illustrate the thought stimulus they had done in class. 
The second phase involved the research conducted at two elementary schools. This phase described the fifth-grade elementary school teacher's stimulus for developing the students' mathematical thinking abilities that occurred in the field. The elementary schools involved were Plalangan 01 and Pakintelan 01 public elementary school in Gunungpati Semarang. Observation of the implementation of mathematics learning in each of the schools was carried out four times during face-to-face learning in August-September 2018. The result of the second phase is a triangulation of the result of the first phase.

The final result involved descriptions of the stimulus form of a fifth-grade elementary school teacher on mathematics learning in developing students' mathematical thinking abilities. The third phase was the recommendation of a thinking stimulus, which was suitable for mathematics learning for fifth-grade elementary schools. The research phases are presented in Figure 1 below.

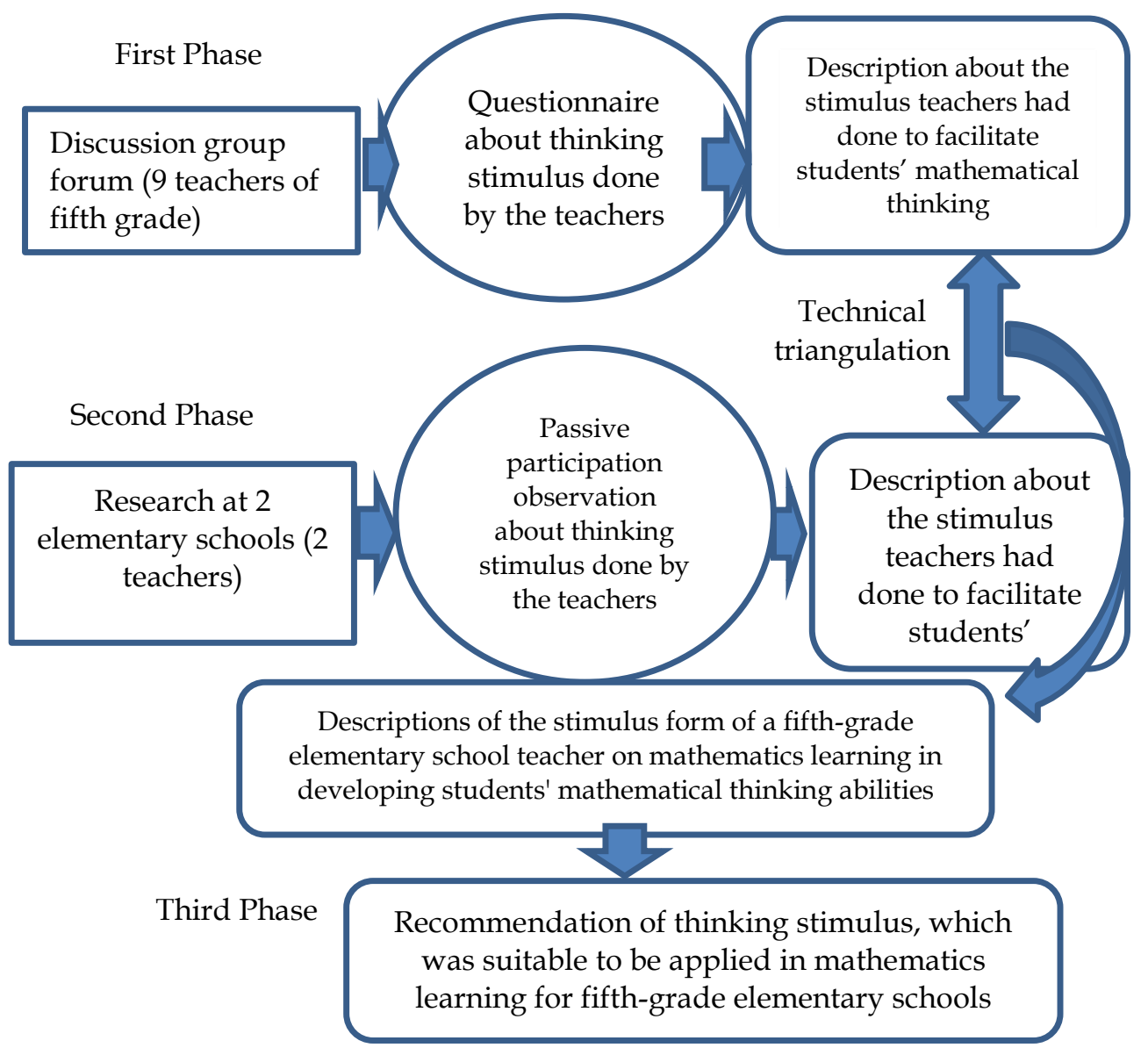

Figure 1: The research phase

\subsection{Instruments}

The research subjects were fifth-grade teachers of state elementary schools in the Regional Technical Implementation (Unit Pelaksana Teknis Daerah) in Gunungpati, Semarang. Both methods of sampling including purposive and snowball sampling techniques were used. For phase 1 activities, research subjects were determined by purposive sampling, a data source sampling technique with specific considerations. Nine fifth-grade elementary school teachers were selected 
from nine different elementary schools, with the following considerations:

(1) In the Teacher Working Group in the Regional Technical Implementation (Unit Pelaksana Teknis Daerah) Gunungpati Semarang, there are four clusters (gugus): Dewi Kunthi, Laras Asri, Drupadi, and Srikandi. Nine of the selected fifth-grade elementary school' teachers are teachers in state primary schools in the Dewi Kunthi cluster and the Laras Asri cluster.

(2) The school's location is close to the university and needs to be involved in higher education research activities.

(3) Advice from the head of the Dewi Kunthi cluster.

(4) Nine fifth-grade teachers from nine public elementary schools were willing and open to be the subjects of research.

For phase 2, the research subjects were determined by snowball sampling. Snowball sampling is done by searching for subjects that are likely to get information in phase 2. Using snowball sampling, two fifth-grade elementary school teachers were selected out of the nine fifth-grade elementary school teachers involved in phase 1 . Both of these fifth-grade teachers volunteered to serve as research subjects in phase 2 .

Data collection methods used in this study were open-ended questionnaires and passive participation observations. The questionnaires were teacher stimulus questionnaires in the first phase. Passive participation observations were carried out by observing teacher learning in the second phase of the study through participatory observation. The researcher presents in the learning activities carried out by the two elementary school teachers each during four mathematics learning meetings in class. With this participant observation, the thought stimulus data provided by the teacher is clearly visible. The type of participatory observation of this study is passive participation observation -i.e., the researcher comes to the place of the observed activity (fifth-grade of Plalangan 01 public elementary school and Pakintelan 01 public elementary school), but is not involved in the teaching and learning activity.

\subsection{Data Validation}

Data are required to meet standards of credibility, transferability, dependability, and confirmability (Siswono, 2007). In this study, credibility of the data was carried out by persistent observation of the implementation of learning in Plalangan 01 public elementary school and Pakintelan 01 public elementary school. The research also used technical triangulation to validate the data i.e., comparing the data from the questionnaire and observation results, as technical triangulation aims to obtain the data regarding the types of teacher stimulus. For the other activity, the researcher held discussions with the research team. Transferability described, in detail, the stimulus types given by the teacher in mathematics learning. Dependability was carried out by an audit technique that maintains the honesty and the accuracy of the researcher's perspective. This research satisfied confirmability because it was based on data exploration of the truth. 


\subsection{Data Analysis}

This study used descriptive analysis to describe the stimulus types given by the teachers in mathematics learning. Miles and Huberman model was used to analyze the data. This model involved data reduction, data display, and conclusion phases. Interview data analysis was performed with data reduction, data presentation, and conclusion drawing steps. Reducing data means summarizing, choosing the main things, focusing on the important things, looking for themes and patterns, and discarding unnecessary ones (Sugiyono, 2016, p. 338). All data information obtained using questionnaires and observation sheets in phases 1 and were collected, then reduced to obtain the data needed for the analysis process; data that did not support the analysis process was discarded.

This study's reduction activity was to simplify the questionnaire and observation sheet results into a suitable arrangement of languages and then transform them into notes, discarding those found unnecessary. The presentation of data is done in brief descriptions, charts, relationships between categories, and others. The reduced data will be organized and arranged in a relationship pattern through the presentation of data to be more readily understood. The presentation of data will make it easier for researchers to understand what is happening and plan the next steps based on what has been understood. The research data will be presented tabularly to make it easier for readers to understand; specifically, this presentation includes data classification and identification. Conclusions are drawn using the results of questionnaires and observations to coalesce the stimuli thought by the teacher.

\section{Research Findings}

\subsection{Finding of The First Phase}

Regarding the Act of the Government Regulation No. 74 of 2008 (Government Regulations, 2008) mandated that teachers must have a minimum qualification academic S-1 or D-IV, competencies (pedagogic, personality, social, and professional) as learning agents, and educator certificates. Therefore, teachers have to continuously improve their competencies continuously improve their competencies through various training, scientific writing activities, workgroup meetings, and workshop discussions, including the teacher working group. The teacher working group, one of the professional forums for teachers (both class and subject teachers) in a regency/city/district/studio/school group, is a nonstructural school organization that is independent, family-based, and has no hierarchical relationship with any other institutions (Al Rasyid, 2017). The teacher working group is a forum for the teachers. Working group activities included exchanging ideas for solving learning problems, sharing learning information, and discussing the challenge of difficult learning material such that a mutual solution is needed. Thus, the teacher working group serves as a strategic effort to improve teacher performance and teaching ability.

Due to the reasons above, this study involved teachers working group to obtain the data. The first phase of the research was a discussion group forum with nine teachers of the fifth-grade elementary school in a teacher working group setting. Teachers were given questionnaires to find out teachers' stimulus types in 
thinking development. Based on the questionnaire results, the teacher's stimulus most often given in mathematics learning is presented in Figure 2 below. Based on Figure 2, student utilization of technology, self-made manipulative props, math games, investigations, and adventure activities outside the classroom were not optimal.

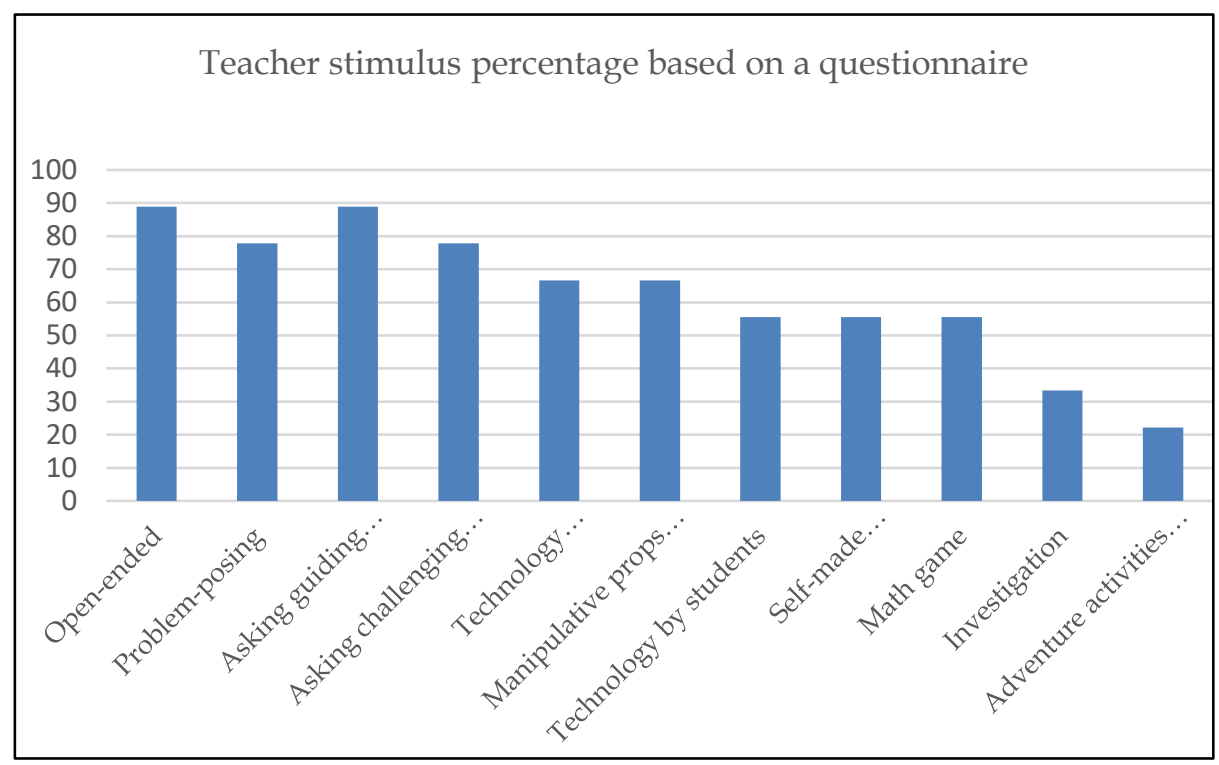

Figure 2: The percentage of teachers' stimulus by questionnaire

\subsection{Finding of The Second Phase}

The second phase was conducted in two elementary schools, namely Plalangan 01 and Pakintelan 01. This phase was conducted to confirm the results of the first phase. The questionnaire result was technically-triangulated with the learning result observation in the field. Based on field research in Plalangan 01 public elementary school and Pakintelan 01 elementary school for four occasions of learning, data on the teachers' stimulus follow. The fifth-grade mathematics teachers in both schools always used a thinking stimulus that asked guiding questions. The teacher gave the guiding question to help the students identify concepts and strengthen their understanding of those concepts.

The Plalangan 01 elementary school teacher taught multiplication and division of fractions and percentages by providing a stimulus in the form of a song. The song used is "Menanam Jagung" (translation: "Planting Corn") by Mrs. Sud (Figure 3a, b), and the lyrics of "Pecahan" song were changed by the teacher to embed the concept of fractions (Figure $4 a, b$ ).

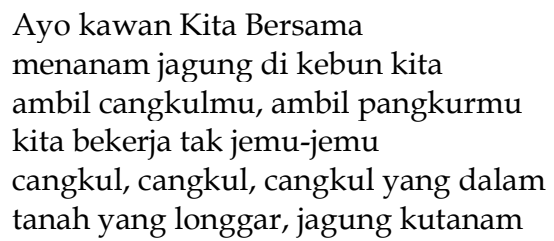

Ayo kawan Kita Bersama menanam jagung di kebun kita ambil cangkulmu, ambil pangkurmu kita bekerja tak jemu-jemu cangkul, cangkul, cangkul yang dalam tanah yang longgar, jagung kutanam

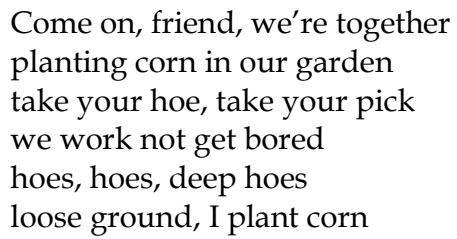

b

Figure 3: a) Lyrics of "Menanam Jagung" song, b) Lyrics of "Planting Corn" song 
Ayo kawan kita bersama

Membagi angka jadi pecahan

Atas pembilang, bawah penyebut

Janganlah sampai terbalik-balik

Kali dengan bilangan yang sama akan

jadi pecahan senilai

Bagi dengan bilangan yang sama akan

jadi pecahan senilai
Come on, friend, we're together

Divide numbers into fractions

The top is numerator; the bottom is a

denominator

Don't turn it upside down

Times with the same number will be

equivalent fractions

Divide by the same number will be

equivalent fractions

a

b

Figure 4: a) Lyrics of "Pecahan" song, b) Lyrics of "Fractions" song

Also, the teacher provided a stimulus in the form of problem posing, giving several numbers in the forms of integers, decimal numbers, and percents (Figure $5)$.

$3 ; 5 ; 6 ; 8 ; 12 ; 15 ; 20 ; 25 ; 20 \% ; 25 \% ; 30 \% ; 45 \% ; 0.20 ; 0.25 ; 0.45$

Figure 5: Numbers for problem posing

In learning about addition and subtraction of fractions, the teacher presents contextual math problems unusually. As a variation in giving the mathematical problem to develop thinking, the teacher provided several contextual problems about fractions presented using Plickers application. Plickers stands for Paper Clickers. Plickers technology is a web-based application that uses synchronization between a smartphone and a computer or PC. The free Plickers application allows teachers to get answers from students quickly. At the beginning of learning, the teacher gives a special paper containing the answers A, B, C, and D. After the teacher raises the questions and students finish working on them, students are asked to show the teacher the Plickers paper with the answers they selected above. After that, the teacher only has to scan the answer paper using the smartphone's camera. Students' answers and true mistakes will automatically appear on the computer screen. Figure 6 below shows some of the teacher's problems in class and the name of the student who worked on it. 


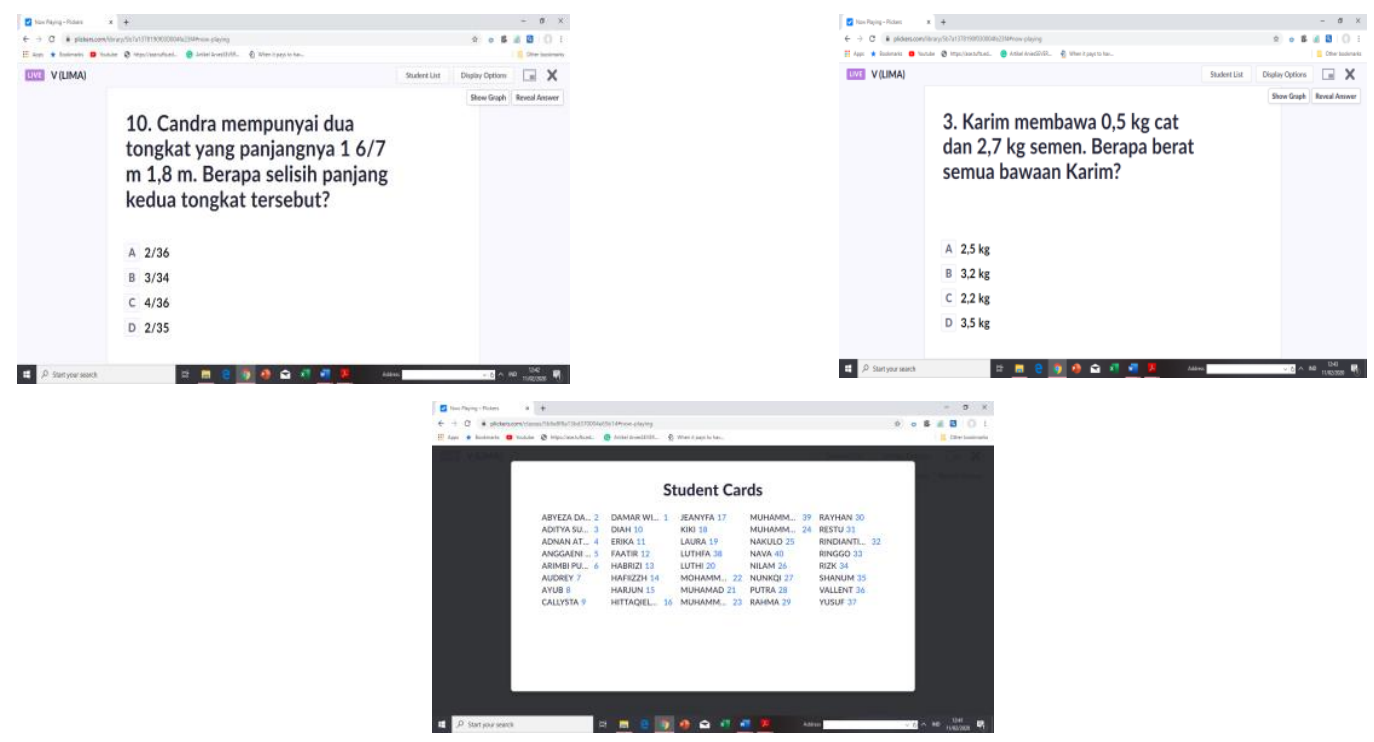

Figure 6: Display of mathematical problems using Plickers. The other facilitation technology used by the teacher for teaching distance, time, and speed units were PowerPoint and miscellaneous learning videos

The teacher of Pakintelan 01 public elementary school taught distance using the song "Naik Ke Puncak Gunung" (translation: "Climb up to the Mountain"). The songwriter was Mrs. Sud, whose lyrics were changed and became the song "Tangga Ukuran" (translation: "Units Stairs"). The teacher stimulated students' thinking about changing the units of distance. Original lyrics of the song "Naik Ke Puncak Gunung" (and then translated as "Climb up to the Mountain") as well as the song "Tangga Ukuran" (and then translated as "Units Stairs") are presented below (Figure 7a, b; Figure 8a, b, respectively).

Naik-Naik Ke Puncak Gunung

Tinggi-Tinggi sekali.....................2x

Kiri Kanan Ku lihat saja

Banyak pohon cemara.

a

$.2 \mathrm{x}$

Figure 7: a) Lyrics of "Naik Ke Puncak Gunung" song, b) Lyrics of "Climb up to the Mountain" song

Naik-naik Tangga ukuran
Tinggi-tinggi sekali.....................2x
Mili senti desi dan meter deka
hekto dan kilo................2x
Kalau naik bagi sepuluh
Turun kali sepuluh.......................2x

a
Climb up to the unit stairs

So high .................... $2 x$

Milli centi deci and meter deca hecto and kilo $2 x$

If it goes up divided by ten

Goes downtimes by ten $2 x$

b

Figure 8: a) Lyrics of "Tangga Ukuran" song, b) Lyrics of "Units Stairs" song 
To train the students in understanding distance units, the teacher provided a stimulus in the problem-posing form. Students in the groups made questions as well as the answer keys. Also, the teacher gave a stimulus in the form task of contextual problem posing. The following data in Figure 9 resulted from students' was the result of students' work on the contextual problem of changing the distance unit.

1. The distance from Winong village to Kepil village was 7 kilometers. The paved road is 5,000 meters. How many meters did the rest of the way go from Winong to Kepil that unpaved?

2. Fadil has a 500 centimeters band. Then, Nofal asks for a 200 centimeters long ribbon. Fadil's father asks for a 100 centimeters long ribbon. How many meters of the rest of the band did Fadil have?

3. Mr. Eko has 300 centimeters of wood. Mr. Eko cut the wood into two equal lengths, and then the mother used one part of the wood as firewood. How many decimeters of the rest of the wood does Mr. Eko have?

Figure 9: Contextual problem-posing made by the students

\subsection{Finding of The Third Phase}

Based on the observation in the field, the teachers' thinking stimuli are problem posing, asking guiding questions, facilitating technology (learning videos, PowerPoint, and Plickers), and using songs. Based on technical triangulation, the teachers' stimuli were problem posing, asking guiding/challenging questions, facilitation technology (learning videos/PowerPoint/Plickers), and song (Table $3)$.

Table 3: Triangulation for teacher stimulus based on questionnaire and field research (Plalangan 01 and Pakintelan 01)

\begin{tabular}{|l|l|l|}
\hline Questionnare & Plalangan 01 & Pakintelan 01 \\
\hline Open-ended task & - & - \\
\hline Problem posing & Problem posing & Problem posing \\
\hline $\begin{array}{l}\text { Asking questions } \\
\text { (guiding and challenging) }\end{array}$ & $\begin{array}{l}\text { Asking guiding } \\
\text { questions }\end{array}$ & $\begin{array}{l}\text { Asking guiding } \\
\text { question }\end{array}$ \\
\hline Facilitating technology & $\begin{array}{l}\text { Facilitating technology } \\
\text { (Plickers, PowerPoint, } \\
\text { learning videos) }\end{array}$ & - \\
\hline Manipulative prop that has existed & - & - \\
\hline- & Song & Song \\
\hline
\end{tabular}

Based on the research in the field, the teachers' thinking stimuli are problem posing, asking guiding questions, facilitating technology (learning videos, PowerPoint, and Plickers), and using songs. The teachers' teachers' stimuli are problem-posing, asking guiding/challenging questions, facilitation technology (learning videos/PowerPoint/Plickers), and song based on technical triangulation. 


\section{Discussion}

Mathematics learning activities in the classroom carried out by students and designed by the teacher. Teachers need to encourage learning as a cognitive process of students. The teacher points out mistakes, mismatches, cognitive conflicts so that students gain a deep understanding of mathematics. The teacher encourages representation and encourages students to think about thinking. Strategies that can be done are demonstration and teaching, connecting and exploring-giving examples, encouraging students to test ideas, discussing and using mathematical language, encouraging representation and visualization, problem posing, encouraging predictions and providing feedback, raises errors and misconceptions, models and encourages reflection on his thinking, and so on. The teacher provides a stimulus in the form of tasks, activities, activities to help students develop their thinking. The first teacher's stimulus is problem posing. Problem posing helps the students to understand mathematics (Cai, Hwang, Jiang \& Silber, 2015), and the students' learning styles are changed from passive to active with its use (Chinese Ministry of Education, 2011). Problem posing conducted by the teacher in this study was something that can be freely done by friends i.e., the students created the story problem about the distances (see Figure 9). Students in this research were also asked to formulate the question of the problem with the question not being stated, and were provided many integers, fractions, and percentages in order to do so (see Figure 5). This method seemed effective for enabling students to make math problems using a variety of basic mathematical operations (adding, subtracting, multiplying, and dividing).

In this study, the two teachers only used free situation problem posing as shown in Figures 5 and 9. The instruction of the two teachers was "Please create free questions using numbers in the form of fractions, percent, decimals, and integers and then answer it". The numbers provided by the teacher are shown in figure 5 . Then, "Make daily life questions about the distance to the students". The results of the questions made by students are shown in figure 9). Teachers need to learn and try a semi-structured situation or structured situation problem posing. Various strategies for problem posing can be conducted by the teacher to develop students' thinking; in particular, it is a helpful tool for understanding the thinking ability of students' regarding mathematics. By understanding it while posing problems would able to inform the instructional choices that teachers make when teaching in this manner (Xu, Cai, Liu \& Hwang, 2019). This study's first recommendation was that the teacher gives the stimulus of problem posing with another strategy. In other words, making the problem based on the context, and the calculation given, making the problem based on the solution provided, making the sub-problem in finishing the bigger problem, and making the question a "what if" scenario. Based on this research, the results of the teacher's mathematical thinking stimuli were problem-posing, asking guiding/challenging questions, facilitation technology (learning videos/PowerPoint/Plickers), and song.

The teacher played an important role in mathematical learning as a facilitator by asking the question. Submitting teacher questions to students helped students develop their level of thinking. Moreover, the teacher's quality of the questions 
affected the development of students' thinking. This question was the main component in the mathematical learning interaction (Hähkiöniemi, 2017) and influenced the students' learning results. The questions asked by both teachers in this study were to guide concept discovery, and these questions subsequently guided the students' conceptual understanding.

The questions given by the teachers included those that explored a fact or student understanding, called factual questions, and those that gave hints or scaffolding, called guiding questions. Both teachers asked about fractions, distances, times, and speeds in the form of a short answer, low-level question exploring the associated fact, rule, and procedure. One of the criteria of guiding questions is that it asks for a specific answer or for the next step of a solution after facing problem. The following are examples of teachers' guiding questions to help students solve the problem by such criteria (Figure 10).

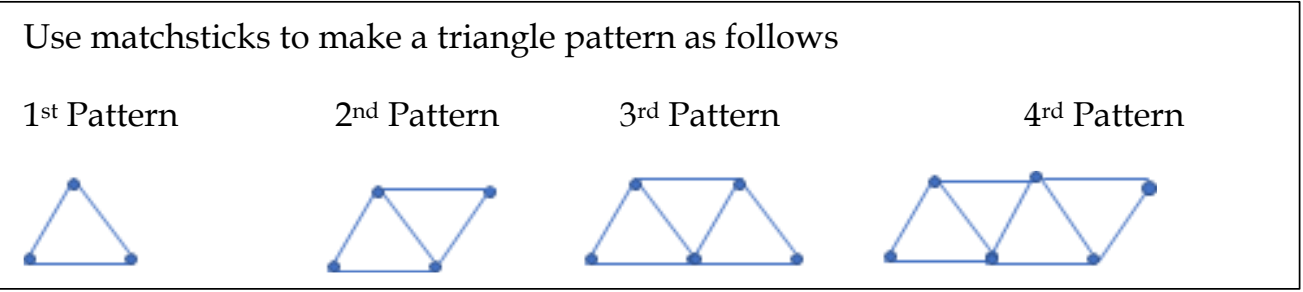

Figure 10: Example of problem used for teachers' guiding question

To answer the problem above, the teacher asks guiding questions. The following are examples of question and answer activities between the teacher and students (Figure 11).

Teacher : How to solve the problem?

Student : (silent)

Teacher : Look at the picture above. How many triangles can be made in each pattern?

Student : Pattern 1 has 1 triangle, pattern 2 has 2 triangles, pattern 3 has 3 triangles, and pattern 4 has 4 triangles

Teacher : Right. Then pay attention to the number of matchsticks in each pattern. How many matchsticks are used in each pattern?

Students : Pattern 1 there are 3 matchsticks, in pattern 2 there are 5 matchsticks, pattern 3 there are 7 matchsticks, and in pattern 4 there are 9 matchsticks.

Teacher : Good. Then how many triangles can be made in the $5^{\text {th }}$ pattern? The $6^{\text {th }}$ pattern? $7^{\text {th }}$ pattern?

Student $\quad:$ (draw $5^{\text {th }}$ pattern, $6^{\text {th }}$ pattern, $7^{\text {th }}$ pattern $)$
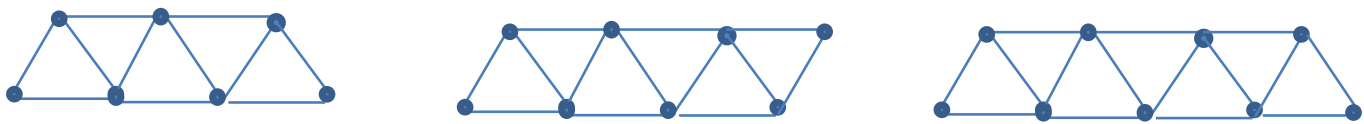

Figure 11: The examples of question and answer activities between the teacher and students 
Teacher : Yes, the picture is very correct. Okay, now count how many matchsticks/sticks were used in the 5th pattern? The 6 th pattern? 7 th pattern? $\left(^{\text {th }}\right.$ pattern is called $5^{\text {th }}$ term, $6^{\text {th }}$ pattern is called $6^{\text {th }}$ term, etc.)

Students : In the fifth pattern, there are 11 matchsticks, in the sixth pattern there are 13 matchsticks, and in the seventh pattern there are 15 matchsticks.

Teacher : Very smart. Now, write down the numbers that show the number of triangles in sequence. Then write down the numbers that indicate the number of matches/sticks in sequence.

Student : (writing)

$\begin{array}{llllllllll}\text { Number of triangles } & 1 & 2 & 3 & 4 & 5 & 6 & 7 & \ldots & \mathrm{n}\end{array}$

$\begin{array}{lllllllll}\text { Number of matchsticks } 3 & 5 & 7 & 9 & 11 & 13 & 15 & \ldots & 2 n+1\end{array}$

Teacher : Right. Now, consider the relationship between the number of triangles and the number of matchsticks.

Student $\quad$ : if there are many triangles, where many matchsticks become $2 \mathrm{n}+$ 1

The low-level question aimed to test the students' understanding. Most of the teacher's questions only needed a short answer and explored the related fact, rule, and procedure. Both teachers rarely asked a high-level question asking the students to give the thinking explanation. Much of the research showed that most of the teacher's questions were low-level questions and that only a few were a high-level question (Alkhateeb, 2019). Most teachers asked questions that measured students' thinking aspects of knowledge and understanding, and few asked questions that measured thinking aspects of analysis and evaluation (Alkhateeb, 2019). In this research, both teachers rarely asked students a question that required them to explain/elaboration/justification, which is referred to as a probing question. The percentage of sixth-grade mathematical teachers asking probing questions ranges from $17 \%$ to $42 \%$. Viirman (2015) noted that the teacher often posed routine inquiries in the form of control questions, asking for facts, inquiries, and rhetorical questions in the mathematical learning context to engage students in the learning process.

In this study, the teacher used the song stimulus. The teacher arranged the song "Naik-naik Ke Puncak Gunung" (translation: "Climb up to the Mountain") by Mrs. Sud to introduce the concept of distance units. In this way, the teacher created the thinking stimulus to make the abstract distance unit concept easier for students to understand. The use of songs in learning helps students remember because it is an effective way to store information for a long time (Bahrami, Izadpanah \& Bijani, 2019). Thus, the song can be used to introduce various mathematical concepts (Noviyanti \& Suryadi, 2019). As singing is a play activity that can be integrated into education and used by the teacher to teach basic mathematical learning, teaching mathematics to the children can be conducted by using a singing technique (Rosli \& Lin, 2018). Mathematics teachers have used the chant "Pleases Excuse My Dear Aunt Sally" for helping students learn about the order of mathematical operation - i.e., adding, subtracting, multiplying, dividing, 
squaring, and so forth. Moreover, children develop the ability to understand and manipulate models using simple rhythms and chants.

The teacher's stimulus in the form of asking a question has various purposes (Warshauer, 2015). These include serving as a means of discussion interaction between the teacher and students, and allowing the students to organize mathematical ideas in finishing a mathematical task. The question is asked sequentially and is carefully developed and built based on the students' ideas, helping evaluate students' thinking. The stimulus form's recommendation for developing mathematical thinking ability was asking the probing question that explains and sheds light on the students' thinking process. This is because the probing question required intellectual effort and led to an increase in student learning to a greater degree than the other type of question. Given that the probing question can be defined as the question that asks students to explain or justify mathematical justification (Kosko, 2016), its influence on students' mathematical achievements tends to be higher.

Asking the probing question in mathematical learning was recommended to construct in the inquiry environment because, in that environment, the teacher can bring up the students' high-level thinking. The learning environments that were planned based on the modeling perspectives had a positive influence on the teacher's ability to qualitatively ask different questions to explore thestudents' high-level thinking (Aydogan Yenmez, Erbas, Cakiroglu, Cetinkaya \& Alacaci, 2018). The teacher developed a math-talk community by increasing the use of probing questions, which in turn reduces teacher effort in providing explainations while increasing support for students' mathematical autonomy.

Mathematical learning in elementary education must be carried out so that mathematics becomes beneficial for children. The strategy that can be conducted is through the use of play and games. Play activity allows children to interact with the concrete object to build their knowledge. Playing gives children valuable experience i.e., children experience using language and symbols, create and carry out the rules, and learn abstract thinking. As a result, children's cognitive abilities (attention, memory, and problem solving) increased. The game is one of the play activities that is useful for developing children's mathematical knowledge. Games are exciting, and they provide the structural experience necessary to helping children to achieve learning purposes (Ramani, Daubert \& Scalise, 2019); they are also socially interactive and utilize children's interest (Hassinger-Das et al., 2017). Games facilitate learning for children with a variety of mathematical abilities, enabling them to interact and learn from each other; in addition, they increase motivation and build a positive attitude towards mathematics (Ramani et al., 2019). For this reason, the recommendations of further thinking stimulus for fifthgrade elementary school students are play and games.

The Teacher Working Group is a forum for elementary school teachers' professional activities at the cluster or sub-district level, consisting of several schools. Teachers need to improve their level of professionalism, especially in terms of developing stimuli to thinking and applying them to classroom learning. 
Teacher professional improvement programs that need particular attention are competency improvement through training, in-service training programs, and increased experience through an internship program or on-the-job training. The bottom-up training model, which is based on the real needs and problems of mathematics teachers in the field, involves developing stimulus-thinking problem posing, asking the guiding question, Plickers/PowerPoint, and Sing a Song; thus, this training helps teachers develop mathematical activities that facilitate students thinking mathematically. The intended training can also be carried out independently through the mathematics teacher community, teacher working groups, or other programs that do not always depend on central or regional government programs.

One of the training models available is INNOMATTS. Since 2013, Asikin, Junaedi and Cahyono (2015) have developed the INNOMATTS model as a training model for Mathematics teachers. The strategy for implementing INNOMATTS is threefold. First, INNOMATTS training can be carried out as part of routine activities scheduled at the Teacher Working Group. A KKG can also carry it out under the auspices of the Education Foundation. Second, INNOMATTS is designed and implemented as a cycle model (as an application of the Deming PD-C-A/Plan-Do-Check-Act cycle), with activities based on group and individual work. For example, group-based activities (activities carried out in clusters) comprise teachers together with other members in one cluster designing (plan) learning tools, and followed up by implementing (do) learning, one as the other model teachers observing and observing results are discussed together again (check). Furthermore, each teacher implements (action) these learning strategies in their respective schools without being observed by peers, and repeatedly (according to the program that is designed as a whole). Third, mentoring by tutors occurs during the training process, both in the cluster and individual activities. Therefore, INNOMATTS can be applied in the teacher working group setting to encourage and foster professional development.

\section{Conclusion}

The in-field stimuli that a fifth-grade elementary school teacher in mathematical learning uses to develop students' mathematical thinking abilities were diverse. Teachers used problem posing, asking guiding questions, facilitating technology in learning videos/PowerPoint/Plickers, and Sing a Song. A fifth-grade elementary school teacher would use the stimulus forms to develop students' mathematical thinking abilities in mathematical learning comprised asking the probing question, play, and games. Further research based on this study result (second year) was developing valid, practical, and effective learning tools to accommodate the thinking stimulus for asking the probing question, problem posing, and mathematical games in the fifth-grade elementary school. Furthermore, the results of the second year's research were widely disseminated to teachers. Primary school teachers who are part of the teacher working group also need to improve their professionalism, especially concerning developing stimulus thinking and applying it in learning. Therefore, the follow-up is the management of learning in the form of INNOMATTS training. Since Asikin et al. (2015) state that the INNOMATTS training model can improve the competition 
and character of mathematics teachers, this model's inclusion would be helpful in follow-up management.

\section{References}

Alkhateeb, M. A. (2019). Assessing eighth-grade mathematics teachers and textbook in embodying thinking levels. International Journal of Instruction, 12(1), 371-388. doi:10.29333/iji.2019.12125a

Al Rasyid, H. (2017). Fungsi kelompok kerja guru (KKG) bagi pengembangan keprofesionalan guru sekolah dasar [The function of the teacher working group (KKG) for the development of elementary school teacher professionalism]. Sekolah Dasar: Kajian Teori dan Praktik Pendidikan,24(2), 143-150. Retrieved from http://journal2.um.ac.id/index.php/sd/article/view/1355/715

Anthony, G., Hunter, J., \& Hunter, R. (2015). Supporting prospective teachers to notice students' mathematical thinking through rehearsal activities. Mathematics Teacher Education and Development, 17(2), 7-24. Retrieved from https:// files.eric.ed.gov/fulltext/EJ1085900.pdf

Asikin, M., Junaedi, I., \& Cahyono, A. N. (2015). Pengembangan model pelatihan innomatts untuk meningkatkan kompetensi dan karakter guru matematika [Development of Innomatts training model to improve the competence and character of mathematics teachers]. Jurnal Penelitian Pendidikan, 32(2), 1-7. doi:10.15294/jpp.v32i2.5713

Aydogan Yenmez, A., Erbas, A. K., Cakiroglu, E., Cetinkaya, B., \& Alacaci, C. (2018). Mathematics teachers' knowledge and skills about questioning in the context of modeling activities. Teacher Development, 22(4), 497-518. doi:10.1080/13664530.2017.1338198

Bahrami, Z. N., Izadpanah, S., \& Bijani, H. (2019). The impact of musical mnemonic on vocabulary recalling of Iranian young learners. International Journal of Instruction, 12(1), 977-994. doi:10.29333/iji.2019.12163a

Cai, J., \& Jiang, C. (2017). An analysis of problem-posing tasks in Chinese and US elementary mathematics textbooks. International Journal of Science and Mathematics Education, 15(8), 1521-1540. doi:10.1007/s10763-016-9758-2

Cai, J., Hwang, S., Jiang, C., \& Silber, S. (2015). Problem posing research in mathematics: Some answered and unanswered questions. In F. M. Singer, N. Ellerton, \& J. Cai (Ed.), Mathematical problem posing: From research to effective practice. New York: Springer. doi:10.1007/978-1-4614-6258-3_1

Chinese Ministry of Education. (2011). Mathematics curriculum standard of compulsory education (2011 version). Beijing, China: Beijing Normal University Press.

Government Regulations. (2008). Peraturan pemerintah nomor 74 tahun 2008 tentang guru [Government regulation number 74 of 2008 concerning teachers]. Jakarta: Departemen Pendidikan Nasional RI.

Hähkiöniemi, M. (2017). Student teachers' types of probing questions in inquiry-based mathematics teaching with and without GeoGebra. International Journal of Mathematical Education in Science and Technology,48(7), 973-987. doi:10.1080/0020739X.2017.1329558

Harel, G., Soto, O. (2017). Structural reasoning. International Journal of Research in Undergraduate Mathematics Education, 3, 225-242. doi:10.1007/s40753-016-0041-2

Hassinger-Das, B., Toub, T. S., Zosh, J. M., Michnick, J., Golinkoff, R., \& Hirsh-Pasek, K. (2017). Más que diversión: el lugar de los juegosregladosen el aprendizajelúdico [More than just fun: a place for games in playful learning]. Infancia $y$ Aprendizaje, 40(2), 191-218. doi:10.1080/02103702.2017.1292684 
Kosko, K. W. (2016). Primary teachers' choice of probing questions: Effects of MKT and supporting student autonomy. International Electronic Journal of Mathematics Education, 11(4), 991-1012.

Lee, M. Y. (2018). Further investigation into the quality of teachers' noticing expertise: A proposed framework for evaluating teachers' models of students' mathematical thinking. EURASIA Journal of Mathematics, Science and Technology Education, 14(11), 1-15. doi:10.29333/ejmste/92019

Lui, A. M., \& Bonner, S. M. (2016). Preservice and inservice teachers' knowledge, beliefs, and instructional planning in primary school mathematics. Teaching and Teacher Education, 56, 1-13. doi:10.1016/j.tate.2016.01.015

Ministry of Education and Culture Republic of Indonesia. (2016). Salinan lampiran peraturan menteri pendidikan dan kebudayaan nomor 21 tahun 2016 tentang standar isi pendidikan dasar dan menengah [A copy of attachment to the regulation of the minister of education and culture number 21 of 2016 concerning the content standards of primary and secondary education].

Ministry of Education and Culture Republic of Indonesia. (2018). Peraturan Menteri Pendidikan Dan Kebudayaan Republik Indonesia Nomor 37 tahun 2018 [Regulation of the Minister of Education and Culture of the Republic of Indonesia Number 37 of 2008].

Munter, C. (2014). Developing visions of high-quality mathematics instruction. Journal for Research in Mathematics Education, 45(5), 584-635. doi:10.5951/jresematheduc.45.5.0584

National Council of Teachers of Mathematics. (2017a). Supporting the common core state standards for mathematics. Retrieved from http://www.nctm.org/Standards-andPositions/Position-Statements/Supporting-the-Common-Core-State-Standardsfor-Mathematics/.

National Council of Teachers of Mathematics. (2017b). Principles and standards for school mathematics: Processes. Retrieved from http://www.nctm.org/Standards-andPositions/Principles-and-Standards/Process/.

Noviyanti, M., \& Suryadi, D. (2019). Conceptualizing mathematical knowledge for teaching of Indonesian teacher in teaching number sense to early childhood. Journal of Physics: Conference Series, 1157(3), 032121. doi:10.1088/1742$6596 / 1157 / 3 / 032121$

Nurlu, Ö. (2017). Investigation of teachers' mathematics teaching selfefficacy. International Electronic Journal of Elementary Education, 8(1), 21-40. Retrieved from https://www.iejee.com/index.php/IEJEE/article/view/95/92

OECD. (2019). PISA 2018 results (Volume I): What students know and can do. Paris: OECD Publishing.

Pepin, B., Gueudet, G., \& Trouche, L. (2017). Refining teacher design capacity: Mathematics teachers' interactions with digital curriculum resources. ZDM, 49(5), 799-812. doi:10.1007/s11858-017-0870-8

Pratiwi, V., Herman, T., \& Lidinillah, D. A. M. (2017). Upper elementary grades students'algebraic thinking ability in Indonesia. International E-Journal of Advances in Education, 3(9), 705-715. doi:10.18768/ijaedu.390554

Ramani, G. B., Daubert, E. N., \& Scalise, N. R. (2019). Role of play and games in building children's foundational numerical knowledge. Cognitive Foundations for Improving Mathematical Learning, 5, 69-90. doi:10.1016/B978-0-12-815952-1.00003-7

Rosli, R., \& Lin, T. W. (2018). Children early mathematics development based on a free play activity. Creative Education, 9(7), 1174-1185. doi:10.4236/ce.2018.97087 
Shaughnessy, M., \& Boerst, T. A. (2018). Uncovering the skills that preservice teachers bring to teacher education: The practice of eliciting a student's thinking. Journal of Teacher Education, 69(1), 40-55. doi:10.1177/0022487117702574

Sugiyono. (2016). Metode penelitian kombinasi (mixed methods) [Combined research methods (mixed methods)]. Bandung: Alfabeta.

Teuscher, D., Moore, K. C., \& Carlson, M. P. (2016). Decentering: A construct to analyze and explain teacher actions as they relate to student thinking. Journal of Mathematics Teacher Education, 19(5), 433-456. doi:10.1007/s10857-015-9304-0

Tofade, T., Elsner, J., \& Haines, S. T. (2013). Best practice strategies for effective use of questions as a teaching tool. American Journal of Pharmaceutical Education, 77(7), 155. doi:10.5688/ajpe777155

Viirman, O. (2015). Explanation, motivation and question posing routines in university mathematics teachers' pedagogical discourse: a commognitive analysis. International Journal of Mathematical Education in Science and Technology, 46(8), 1165-1181. doi:10.1080/0020739X.2015.1034206

Xu, B., Cai, J., Liu, Q., \& Hwang, S. (2019, in press). Teachers' predictions of students' mathematical thinking related to problem posing. International Journal of Educational Research. doi:10.1016/j.ijer.2019.04.005

Warshauer, H. K. (2015). Productive struggle in middle school mathematics classrooms. Journal of Mathematics Teacher Education, 18(4), 375-400. doi:10.1007/s10857-014-9286-3 